\title{
Certificados e outros comprovativos: uma missão do Serviço Nacional de Saúde?
}

Raquel Braga*

A emissão de atestados e certificados médicos é uma actividade inerente à actividade clínica, quer para certificar o estado de boa saúde, quer para comprovar a doença. No entanto, grande parte destes atestados, solicitados a médicos que exercem funções no Serviço Nacional de Saúde, são utilizados no âmbito profissional, de actividades de lazer, para condução de veículos, entre outras finalidades, não estando ligados a um benefício directo da saúde do utente ou a uma protecção relativa à doença.

Argumentam os colegas mais prestáveis, mais atentos às necessidades dos utentes, quer sejam estas do âmbito da saúde, quer sejam do âmbito social, que ninguém melhor que o Médico de Família para emitir certificados, pois é o médico que melhor conhece o doente e que está mais habilitado, de forma bem circunstanciada, a fazê-lo.

No entanto, entre estes médicos que conhecem bem os seus doentes e que encaram de bom-grado a emissão de atestados de qualquer tipo (não sentindo que esta actividade lhes retira tempo para efectuar outras consultas relacionadas directamente com a resolução de problemas de saúde), há sensibilidades diversas. Há alguns a quem choca o uso e porte de armas, as actividades de caça ou venatórias, embora possam não chocar as actividades relacionadas com a condução de veículos automóveis, seja no âmbito profissional ou não. Esta plêiade de sensibilidades, completamente lícita no exercício da actividade clínica de cada médico, não se torna prática nem legítima do ponto de vista do cliente, por não ser igualitária no acesso aos serviços prestados por um serviço público.

Todas estas situações a atestar, para as quais é necessário estar de boa saúde e que podem afectar a vida de outros seres, merecem ser encaradas com toda a seriedade, ética e deontologia, mas não podem ser confundidas com actos médicos que beneficiam a saúde do doente ou o protegem de adoecer.

*Directora da Revista Portuguesa de Medicina Geral e Familiar
Nesse sentido, consultas para emissão de atestados não deveriam constituir uma obrigação do Estado, isto é, serem comparticipados pelo erário público, já que não são motivadas por razões de saúde, mas sim por questões práticas (como a habilitação para conduzir) ou permissão para a prática de actividades desportivas ou de lazer (como atestados para caça, pesca submarina, ou prática desportiva, etc.) e, repare-se, sempre por interesse ou conveniência individual...

Deverá um qualquer contribuinte comparticipar através dos seus impostos uma consulta que vai resultar na emissão de um atestado para licença de porte de arma ou para uma licença de caça? Por que razão deverão contribuintes que não têm capacidade económica para ser proprietários de um carro, veículo motorizado ou velocípede ajudar a comparticipar as consultas dos candidatos a condutores ou, sobretudo, verem o seu tempo de acesso a cuidados médicos condicionado por este tipo de actividades secundárias do ponto de vista da finalidade do Serviço Nacional de Saúde?

Centremo-nos na questão de fundo deste editorial: a nova legislação ${ }^{1}$ acerca das cartas de condução, que ignora por completo os projectos de legislação que previam a criação de Centros de Inspecção privados ${ }^{2}$ para passar a imputar a responsabilidade pela emissão de atestados para carta de condução a qualquer médico no exercício da sua função, empurrando-a descaradamente para os Médico de Família.

Esta legislação encerra dois aspectos contraditórios:

- Permite a qualquer médico no exercício da sua profissão emitir um atestado para a carta de condução de qualquer grupo - o que é prático;

- Impede qualquer médico respeitador da lei de o fazer sem recorrer ao parecer de outros médicos, na esmagadora maioria dos casos - o que é deveras limitador.

Esta legislação parece ainda padecer de alguns complexos de culpa: ao ultrapassar a criação dos Centros de Inspecção, parece querer redimir-se dando a oportunida- 
de de se poder resolver o assunto a expensas e com o aval de um serviço público, usando os Médicos de Família do Serviço Nacional de Saúde e o parecer dos médicos de especialidades hospitalares. No entanto, cria trâmites tão rigorosos e específicos que inviabiliza a emissão de atestados em tempo útil, pela necessidade de múltiplos pedidos de parecer.

Este facto, que não será prático, nem cómodo para o utente, vai-se reverter em pressão sobre o Médico de Família. Este ver-se-á tentado ou até coagido a ultrapassar a lei para, usando argumentos interiores que passam pela sensatez do seu juízo clínico, ir ao encontro da vontade e da «urgência» do utente para cumprir prazos que lhe permitam continuar a conduzir ou a trabalhar. Ninguém é imune ou insensível a este constrangimento da vida prática... Mas, desenganem-se os beneméritos, a sensatez do juízo clínico ou os plácidos argumentos lógicos não se sobrepõem às exigências da actual lei.

Porque já me deparei com essas situações, interrogo-me se, na sequência das exigentes premissas da avaliação clínica consignadas na nova legislação, os médicos dispostos a ir ao encontro das necessidades dos utentes, facilitando-lhes a emissão desses atestados, estão dispostos a incumprir a lei, ultrapassando a necessidade de pareceres que a esmagadora maioria dos casos condiciona?!

Por último, mas deveras perturbador e perverso: solicitar, sob a capa enganosa da facilitação e da proximidade com o doente, que o Médico de Família, aquele que é o médico mais próximo e assume um papel de defesa e advocacia do doente, seja o fiscal e executor que coloca as restrições e as inibições de conduzir.

Se esta questão já se colocava anteriormente acerca da emissão de atestados para a condução de veículos do grupo 1 , sobretudo nos indivíduos idosos em que a restrição de conduzir pode ser sentida como uma grave perda de independência ou autonomia, ${ }^{3,4}$ passa-se agora também para os condutores profissionais.

Vamos ter situações perversas de condutores profissionais que passarão a esconder sintomas e problemas de saúde que limitem a emissão destes atestados aos seus Médicos de Família? Como será a relação de confiança entre o Médico de Família e o seu doente, depois de este lhe retirar a possibilidade de aceder à sua forma de sustento ou ao símbolo da sua autonomia?

A avaliação médica para a condução pode ser uma questão deveras sensível e dificil, particularmente quando envolver determinadas condições de saúde. ${ }^{5}$ Estas questões dizem respeito ao paciente e ao médico e deve- riam envolver uma entidade reguladora com responsabilidades não só relativamente ao avaliado (sobretudo se se tratar de uma pessoa doente) como a toda comunidade rodoviária. Em certos países, como na Austrália, em que se imputou a maior responsabilidade pela aptidão para a condução ao médico assistente, verificou-se terem-se criado condições para surgirem conflitos de interesse que podem conduzir a situações de falta de segurança e de prejuízo da relação médico-doente, interferência na orientação clínica do doente e vulnerabilidade legal para o médico. Neste enquadramento sugere-se que o médico assistente forneça informação clínica em vez de emitir um parecer. Este deve ser emitido por peritos independentes e sem conflitos de interesses para com os avaliados. ${ }^{5}$

Como médicos, não podemos misturar papéis antagónicos, nem pactuar com situações absurdas. Esta legislação deve ser revista, a bem da segurança pública, do serviço de saúde, dos Médicos de Família e muito em breve dos médicos de especialidades hospitalares, que não poderão suportar o peso de tantas consultas com a finalidade de pedidos de pareceres...

Esta lei deve ser revista, sobretudo por causa dos cidadãos que circulam nas ruas e que, por acaso e noutra condição muito distinta, são utentes do Serviço Nacional de Saúde.

Não sobrecarreguemos ainda mais o Serviço Nacional de Saúde, já em condições precárias na sua sustentabilidade. Não esqueçamos que este tem obrigação de dar resposta a questões de saúde e não deve ser desviado disso por questões acessórias...

\section{CONFLITO DE INTERESSES}

A autora é Presidente do Conselho Clínico do ACeS de Matosinhos

\section{REFERÊNCIAS BIBLIOGRÁFICAS}

1. Decreto-Lei n. ${ }^{\circ}$ 138/2012. Diário da República, 1. a série - N. ${ }^{\circ} 129$ - 5 de Julho de 2012.

2. Decreto-Lei n. $313 / 2009$. Diário da República, 1. ${ }^{\text {a }}$ série - N. ${ }^{\circ} 208$ - 27 de Outubro de 2009.

3. 1. Carr DB, Duchek JM, Meuser TM, Morris JC. Older adult drivers with cognitiveimpairment. Am Fam Physician 2006 Mar 15; 73 (6): 102934.

4. Sayanda I. Idoso e condução. Rev Port Clin Geral 2006 Nov-Dec; 22 (6): 755-60

5. Somerville ER, BlackAB, Dunne JW. Driving to distraction: certification of fitness to drive with epilepsy. Med J Aust 2010 Mar 15; 192 (6): 342-4.

\section{ENDEREÇO PARA CORRESPONDÊNCIA}

director@rpcg.apmcg.pt 